\title{
West Side Story in a Post-Communist Parliament: Effect of Gender on Legislative Behaviour of $\mathrm{MPs}^{1}$
}

\begin{abstract}
There is vast evidence that gender influences the legislative behaviour of MPs. Nonetheless, as most of the findings come from Western Europe, one may ask whether such effects take place similarly also in post-communist parliaments. Since the two regions experienced different gender-related history, a negative answer suggests itself. By contrast, this first complex research on the issue conducted in a post-communist country demonstrates the opposite. It employs parliamentary activity of representatives in the Czech Republic between 1993 and 2017 as a research case. Results of the analysis show that although female MPs speak less, they receive more positions in intra-parliamentary bodies than male deputies. Moreover, a majority of committees are far from being gender-neutral as male and female legislators have significantly different chances of becoming their members. Overall, the results suggest that gender influences MPs' parliamentary behaviour even in post-communist countries, and surprisingly similarly to Western Europe.
\end{abstract}

Key words: Gender, parliament, legislative behaviour, Czech Republic, Chamber of Deputies

C ountless evidence shows that gender affects the legislative behaviour of MPs (e.g. Childs, 2004; Hogan, 2008; Wängnerud, 2009; Koch, Fulton, 2011; Bäck et al., 2014; Geys, Mause, 2014; Wilson, Carlos, 2014; Gwiazda, 2017; Chiva, 2018; Gwiazda, $2019 b$ ). However, most of the findings come from Western European legislatures. Thus, one may ask whether such effects work similarly in a post-communist region.

The main reason for the research imbalance is straightforward - Western Europe has a more extended history of democratic parliamentarism. Contrary to this, communist legislatures were nothing but 'rubber stamp' institutions that did not allow the effect of gender to be displayed in its true colours (Mansfeldová, 2011). Today, parliaments in Central and Eastern European post-communist countries have already operated under democratic rule for three decades. Still, the study of female political representation in post-communist states is lacking (Gwiazda, 2019a). Despite that, it is not justifiable to blindly copy the findings on gender effects on MPs' legislative behaviour from Western Europe - it would be naïve to expect the very same pattern to appear also in post-communist countries.

The two regions have experienced a very distinct gender-related history. While there was a sexual revolution in the 1960s in the West, the communist bloc persisted in defending the traditional model of the family. While a post-materialist transformation raising gender issues took place in the $1970 \mathrm{~s}$ in the liberal democracies, the authoritarian regimes did not allow anything of the sort. While women were gradually becoming eman-

${ }^{1}$ The author would like to thank Diana O'Brien, and Miloš Brunclík. This work was supported by the Charles University, Charles University Grant Agency [grant number 234217]. 
cipated in the free world, female citizens and politicians behind the Iron Curtain faced oppressive patriarchy for forty years.

Therefore, the distinct societal and political evolution of the two regions suggests that the Western effects of gender on MPs' legislative behaviour would not work in the same way in post-communist countries. To verify this hypothesis, I scrutinise the legislative behaviour of MPs in the Czech Republic as a research example. The Czech Republic went through the most rapid and successful democratic consolidation in the region. Thanks to this, Czech deputies have worked predominantly under similar rules and conditions as their colleagues in the West. Nonetheless, the country still experienced a communist regime. Therefore, the Czech case allows us to evaluate whether gender influences MPs' parliamentary work similarly to Western Europe, regardless of the communist legacy. Last but not least, there has not yet been a comprehensive study of the differences between Czech female and male representatives, which also makes the article a pioneering case study.

I employ a quantitative analysis of the deputies' parliamentary performance between 1993 and 2017. Considering the amount of the data, it makes for uniquely complex research. The results suggest that gender does influence the parliamentary behaviour of MPs in the Czech Republic. However, the differences are not radical. The findings imply that despite women's descriptive underrepresentation in the Czech legislature, female MPs are similarly active, in terms of their parliamentary performance, as male deputies, with only a few exceptions.

Although female MPs speak less often than their male colleagues, they receive more positions in intra-parliamentary bodies compared to male deputies. Interestingly, these differences have been increasing over time. Finally, on the one hand, contrary to their male counterparts, female deputies have significantly higher chances of becoming members of committees dealing with science, health care, social policy, petitions, or legal affairs. On the other hand, there is a substantially higher probability that men rather than women MPs will become members of committees on economic affairs, budget, security, and agriculture.

Most importantly, the analysis implies that gender tends to affect the legislative behaviour of MPs in the Czech Republic similarly to that in Western Europe. The evidence for this is the fewer speeches by female MPs and gender-biased committees. The communist heritage is indeed the most vocal difference between the Western and post-communist Europe. Thus, if gender manifested differently in post-communist parliaments compared to Western European legislatures, one could blame the communist legacy first. However, based on the article's findings, a communist heritage does not seem to play a significant role here. The West side story can take place even in a post-communist parliament.

\section{Role of MPs' gender}

The number of women in politics throughout the world has been increasing in recent decades. In August 1998, the proportion of women in national parliaments was 12.7 per cent, and the number rose to 18.2 per cent in 2008 . The figure from 2018 already shows that the proportion expanded to 23.8 per cent. As a result, today, there are 35 national as- 
semblies in the world with more than a third of female MPs (Inter-Parliamentary Union, 2019).

However, representation is a multi-layered phenomenon. Besides other meanings, Pitkin (1967) differentiates between a descriptive and substantive representation. The former focuses on the extent to which representatives reflect those represented. The latter stands for pushing through the interests of those represented (Dovi, 2007).

The initial research on women in parliaments inspected their mere presence in legislative bodies. Today, scholars are dealing mostly with women's substantive representation. The turn took place after Anne Phillips published the influential book The Politics of Presence (1995). She suggested that there was a link between descriptive and substantive representation, as female politicians represented women's interests in the best way (Wängnerud, 2009). Later research added that not all descriptive representatives were the same. This means that the preferable ones "have strong mutual relationships with dispossessed subgroups" (Dovi, 2002, emphasis in original).

A causal mechanism of gender's effect on MPs' legislative behaviour resides in the legislative recruitment process, which is different in the case of men compared to women. In their seminal work, Loewenberg and Patterson (1979) employed the metaphor of a funnel. On the one side, there are a lot of citizens eligible for office, and on the other side, only a few who become MPs. It is a procedure of many phases and "at each stage in this process, women can face gender specific impediments" (Matland, Montgomery, 2003).

Studies in liberal democracies have shown that female political recruitment depends on a combination of political, socioeconomic, and cultural factors (Norris, Lovenduski, 1995; Matland, 2005). For example, there are fewer female than male politicians due to the traditional role of women as caretakers. Female politicians are also oppressed within male-driven parties. Last but not least, voters prefer male candidates, due to gender stereotyping. As a result, female MPs are different and behave differently compared to their male counterparts, since the two genders did not go through the same recruitment process.

Moreover, even if two representatives of the different genders had experienced the very same chances of career advancement, their legislative behaviour would not have been the same. Female MPs point out their particularities, such as consensus-seeking and gentleness (Galligan, Clavero, 2008). Women MPs in the British Labour Party claim that women are less combative and aggressive, more collaborative and speak in a different language compared to men (Childs, 2004). The data from five Western countries suggest that female politicians combine feminine non-verbal communication patterns and masculine verbal expressions (Grebelsky-Lichtman, Bdolach, 2017). Women legislators also have different experiences of health, education, and social protection policies. Thus, it is natural to expect that such differences leave their marks on the legislative behaviour of the two genders, albeit unpredictable in its specific manifestation.

Looking at the detailed evidence, Bäck, Debus, and Müller (2014) elucidate why it is essential to study both descriptive and substantive representation together. In Sweden, 43.6 per cent of MPs are women, and the country boasts about its descriptive representation. Nonetheless, female deputies deliver fewer speeches on hard policy issues such as macroeconomics, transportation, or banking than men. Although almost half of the MPs are female, the performance in parliamentary activities is not equal. 
Still, there are transnational findings that female MPs defend feminist interests more than their male colleagues. Lloren (2015) delivers such a conclusion using data from Switzerland. In Argentina, more women's rights bills were proposed when females held a larger portion of seats in both chambers of the parliament (Htun et al., 2013). Canadian female MPs speak on women's issues more than their male colleagues (Tremblay, 1998). Importantly, a scrutiny of the US Congress implies that female representatives are no less effective in turning policy preferences into law than their male counterparts (Jeydel, Taylor, 2003). On the contrary, female representatives sponsor and cosponsor significantly more bills than male MPs (Anzia, Berry, 2011).

Female legislators emphasized their representing women's issues in the past. For instance, in the Weimar Republic, there was a decisive impact of gender on the representatives' voting behaviour on a legal proposal to curb the spread of sexually transmitted diseases (Debus, Hansen, 2014). To be more specific, women were not afraid to deviate from the party line if women's interests were at stake. The evidence from today shows that intra-party gender differences in political opinions seem to be most significant on issues where women are particularly affected (Heidar, Pedersen, 2006).

The increasing presence of women in national parliaments today not only helps to promote female issues, but it also changes the political environment in general. Employing the data collected between 1970 and 2003 from 22 established democracies, Koch and Fulton (2011) show that the higher the proportion of female MPs there was, the less conflict behaviour and defence spending there was. Furthermore, the increased presence of women in the Swedish parliament changes policy positions of whole parties, and issues such as gender equality, and social welfare are more prioritised (Wängnerud, 2000). In the US Congress, female representatives hire more women as their congressional staff (Wilson, Carlos, 2014). Other cross-national research shows that in countries with more female MPs, adolescent girls are more likely to discuss politics and to intend to participate in politics as adults (Wolbrecht, Campbell, 2007).

Another field of the study suggests that women and men are not always equally represented in intra-parliamentary bodies (Towns, 2003; Heath et al., 2005). In Belgium, female MPs are more likely to be assigned to a committee that they did not request (Diaz, 2005). In Sweden and Norway, women have been consistently overrepresented in culture, education, health, and social affairs committees. By contrast, they have been underrepresented in the defence, finance, and industry committees (Towns, 2003). However, this is not the case in every country. In the British House of Commons, the composition of committee membership indicates gender-neutral outcomes (O'Brien, 2012). In Scottish and Welsh parliamentary committees, too, women are represented similarly to men (Brown et al., 2002).

Importantly, the summary of the essential findings shows that they predominantly come from the Western world (mainly Western Europe). Nonetheless, one might expect that the effect of gender on MPs' legislative behaviour works differently in the postcommunist region. Gender-related public debate in the East is not as loud as in the West, and more gender stereotypes persist in the former compared to the latter.

The distinction is not caused only by the communist heritage but also by the traditionalist culture in Central and Eastern Europe (Gwiazda, 2019a). The gender issue manifests itself through complex effects. Thus, one may anticipate more extensive, or even a lack of influence of gender on MPs' legislative behaviour in post-communist leg- 
islatures compared to the Western ones. Nonetheless, scholarly studies provide evidence that gender works similarly in the two regions.

Western European states experienced a sexual revolution in the 1960s and postmaterialist transformation in the 1970s (Inglehart, 1977). Among other things, these movements have substantially changed the societal and political arenas. For instance, the effect of these movements on parliaments and thereby on female representation has become much more influential as the movements in the Western world have changed people's views on gender differences (Saxonberg, 2000).

Contrary to this, post-communist societies did not go through similar transformations until the 1990s (if at all). In fact, the countries in Central and Eastern Europe faced social and political stagnation for forty years. In the era of authoritarian communist regimes, men were absolute occupiers of the public domain. Furthermore, feminist discourse was almost entirely absent. Despite changes similar to those in Western Europe which followed, most of the contemporary politicians and voters were raised during times of deep gender inequality. Furthermore, the conditions remained imbalanced to some extent even after the democratic revolutions, since the new democracies were "male democracies" (Eisenstein, 1993).

Even today, female politicians in post-communist states identify lack of confidence, problems in reconciling work and family life, and gender stereotyping as primary barriers to representation (Galligan, Clavero, 2008). To be more specific, women legislators from Bulgaria, the Czech Republic, Hungary, Poland, Romania, Slovakia, and Slovenia point out voters' preference for male candidates (see Madsen, 2019). Furthermore, they complain about the oppression within male-driven parties and the perception of women as caretakers. Such observations imply that gender leaves its marks on the legislative behaviour of MPs even in post-communist parliaments.

The legitimacy of the assumption is also confirmed by a growing number of studies that have focused on the relationship between gender and politics in the region. Thus, we can read about the effects of electoral systems on women's representation (Moser, 2001), gender quotas (Gwiazda, 2017), female substantive representation (Gwiazda, 2019b; Ilonszski, Vajda, 2019), or the descriptive representation of women in the region (e.g. Saxonberg, 2000; Ilonszski, 2006; Jankowski et al., 2019). Furthermore, there are various books on the relationship between gender and political institutions in Central and Eastern European countries (e.g. Galligan et al., 2007; Rueschemeyer, Wolchik, 2009; Chiva, 2018). Although such studies deliver valuable conclusions, findings on the causal effects of gender on MPs' legislative behaviour in post-communist parliaments are still missing (Gwiazda, 2019a).

Fortunately, it is possible to gather at least some relevant evidence from the Czech Republic. To be more specific, we know that female MPs are more likely to vote according to party line than their male colleagues (Stegmaier et al., 2016). Such an effect is insignificant in Poland, and the authors imply that Polish gender quotas for candidate lists may be the explanation - the Czech Republic does not have such a law (see below). As a result, female MPs in the Czech Republic do not feel as secure about their political prospects as their colleagues in Poland (Stegmaier et al., 2016).

Further evidence also proves the tough political position of women in Czech politics. A public survey from February 2016 shows that only half of the respondents said that both genders should carry out public offices equally (CVVM, 2016). Almost 40 per cent 
of the people think that it is mainly a job for men (the rest did not answer). The figures remain approximately the same since the 1990s. On the contrary, buying food, cooking, cleaning, and childcare are perceived as activities for either both sexes or just women (CVVM, 2016).

\section{Effect of gender}

I consider analyses dealing with descriptive and substantive parliamentary representation of women to be equally important. Still, since this is a pioneering study on gender's effect on MPs' legislative behaviour in a post-communist country, I focus primarily on descriptive representation. While such analysis may come before research on substantive representation, the reverse order would not work.

\section{Hypotheses}

Research from Western European countries shows that it is appropriate to expect specific differences between male and female MPs considering their parliamentary activity. Nonetheless, Western European legislatures work under different rules and in an environment of particular historical, societal, and political conditions. Therefore, I take the conclusions from Western legislatures only as a benchmark to be tested in a post-communist country. I employ findings mainly from the British House of Commons, and Scandinavian parliaments, where the effect of gender has been scrutinised repeatedly in the past.

One of the most sound findings on gender-related differences in the legislative behaviour of MPs sheds light on their speechmaking. Bäck and Debus (2016) demonstrate that female MPs in Finland, Norway, Sweden, and Estonia speak less than their male counterparts. The distinction is caused by the fact that women legislators do not address 'hard policy' issues (e.g. macroeconomics, energy, or science) as often as their male counterparts. Interestingly, both groups of representatives address 'neutral' and 'soft policies' (e.g. health, social welfare, or education) with similar frequencies.

Importantly, Bäck and Debus also assessed the case of the Czech Republic between 2006 and 2009 with the conclusion that there is "no evidence that female MPs deliver fewer speeches than their male colleagues in the parliament" (2016). Even though this is an interesting finding, it is based only on three years of the very specific political situation of a hung parliament. Contrary to this, the presented analysis promises to deliver more solid results concerning the period of the data.

To build a full picture, the findings from Germany and Ireland also imply no difference in the speechmaking of male and female MPs. However, the previously described findings suggest an effect of gender on MPs' participation in plenary debates. Thus, I assume the following hypothesis:

\section{H1: Female MPs make fewer speeches compared to male representatives.}

Next, MPs' parliamentary performance is substantially affected by their intra-parliamentary position, such as memberships in committees, subcommittees, and commissions. 
It is often assumed that female representatives get fewer of those positions as a result of gender-bias. By contrast, the evidence shows that in the British House of Commons, women were at an advantage in elections for committee chairs (O'Brien, 2012). One of several reasonable explanations is that female MPs are underrepresented in cabinet, and this is substituted for by positions in intra-parliamentary bodies.

In the Czech Republic, cabinet ministers cannot hold a position in (sub)committees and commissions. At the same time, women have been vastly underrepresented in cabinets since the state's establishment in 1993 (Šprincová, Adamusová, 2014). Therefore, female MPs may be 'rewarded' by intra-parliamentary positions similarly to the House of Commons. In any case, I form the following hypothesis based on the Western finding:

H2: Female MPs get more committee, subcommittee, and commission chairs than male deputies.

Last but not least, the debate on speechmaking has already implied that female MPs deal with different policies compared to male legislators. This effect has also been observed in the case of committee assignments in many parliaments (Thomas, 1994; Towns, 2003; Heath et al., 2005). To be more specific, Towns (2003) scrutinised gender patterns in Swedish (1971-2006) and Norwegian (1969-2005) committees. As a result, he differentiated 'female' committees dealing with health, social affairs, education, justice, and culture. Contrary to this, the 'male' committees focus on agriculture, defence, finance, taxation, industry, and transport.

According to the Rules of Procedure of the Chamber of Deputies, PPGs gain the specific number of committee mandates relative to the size of the group. Subsequently, a filling of the mandates depends entirely on an intra-PPG discussion (Mansfeldová, Linek, 2009). Seniority plays an important role here, but there is also a possibility of MPs selecting their favourite policy agenda, as well as of gender discrimination. Besides this, one has to keep in mind that some committees (e.g. on budget, constitutional and legal affairs) are more prestigious than others (e.g. on petitions, mandate and immunity) (Rakušanová Guasti, 2009).

In the Chamber of Deputies between 1993 and 2017, it is possible to identify 13 committees on (1) agriculture, (2) budget, (3) constitutional and legal affairs, (4) economic affairs, (5) environment, (6) foreign affairs, (7) health care, (8) mandate and immunity, (9) petitions, (10) science, education, culture, youth and sport, (11) security, (12) social policy, and (13) a steering committee. ${ }^{2}$ Employing the previously mentioned findings of Towns (2003), I propose the next pair of hypotheses:

H3a: Female MPs have a higher chance of becoming a member of committees on (1) constitutional and legal affairs, (2) health care, (3) science, education, culture, youth and sport, and (4) social policy than male deputies.

$H 3 b$ : Male MPs have a higher chance of becoming a member of committees on (1) agriculture, (2) budget, (3) economic affairs, and (4) security than female deputies.

Besides these hypotheses, it is possible to make further assumptions based on the findings from the Western world. For example, Anzia and Berry (2011) show that US con-

${ }^{2}$ Between 1993 and 2017, there were more sitting committees. However, only these 13 committees were established in all seven parliamentary terms with a similar political agenda. 
gresswomen sponsor and cosponsor significantly more bills than their male colleagues. To explain this, if there is a bias of voters against women, only the most talented and hardest working females will run for office and also succeed in the electoral process. Given this, one could anticipate that female MPs not only propose more bills, but also ask more questions, attend more roll call votes, and vote more actively. Since these issues are interesting, I will examine them in the following analyses. Nonetheless, as more robust findings are missing, I shall not construct any specific hypotheses about such relationships.

\section{Data}

I shall scrutinise all seven complete terms of the Chamber of Deputies since the establishment of the Czech Republic in 1993 until 2017. I shall focus on the lower house of the parliament, since it is the polity's central institution, thanks to the asymmetrical bicameralism of the Czech parliamentary regime.

During that time, 1,518 MPs held a mandate as deputy. However, I shall exclude $33 \mathrm{MPs}$ who served for less than six months, as they did not have enough time to engage in parliamentary work properly. ${ }^{3}$ Next, I reject 99 legislators who were members of the various cabinets, since their intra-parliamentary position differed too much from that of ordinary MPs. ${ }^{4}$ Furthermore, I cannot quantify the legislative behaviour of Ivana Janů MP, since she held her mandate before the electronic system of recording was installed in December 1993. As a result, I employ a default dataset with information on 1,385 representatives.

Table 1 summarises a descriptive representation of women in the lower house of the Czech parliament. ${ }^{5}$ Initially, there was a post-communist drop in women's representation (Saxonberg, 2000; Galligan, Clavero, 2008; Stegmaier et al., 2014). Before 1989, there was a quota system for women on candidate lists, which also translated into high female parliamentary representation, albeit predominantly passive.

Table 1

Gender of MPs in the Czech Republic

\begin{tabular}{|c|c|c|c||}
\hline Term & MPs & Female MPs & Share of female MPs (\%) \\
\hline 1 & 2 & 3 & 4 \\
\hline $1993-1996$ & 195 & 19 & 9.74 \\
\hline $1996-1998$ & 191 & 30 & 15.71 \\
\hline $1998-2002$ & 196 & 32 & 16.33 \\
\hline $2002-2006$ & 208 & 34 & 16.35 \\
\hline
\end{tabular}

${ }^{3}$ The period of 180 days (six months) was chosen by two different approaches that confirmed the very same result. The first method finds out the approximate length of time spent in office after which the deputies become active (addressing speeches, proposing bills, or delivering interpellations). The second method is a brief survey conducted among deputies asking "after how much time spent in office is a deputy able to perform her mandate responsibly."

${ }^{4}$ For example, MP-ministers are not allowed to be committee members, they are not expected to deliver interpellations, and in general, their ministerial duties substantially influence their parliamentary work.

${ }^{5}$ Descriptive statistics of all the variables is provided in the appendix. 


\begin{tabular}{|c|c|c|c||}
\hline 1 & 2 & 3 & 4 \\
\hline $2006-2010$ & 206 & 37 & 17.96 \\
\hline $2010-2013$ & 193 & 43 & 22.28 \\
\hline $2013-2017$ & 196 & 41 & 20.92 \\
\hline $1993-2017$ & 1,385 & 236 & 17.04 \\
\hline
\end{tabular}

Note: The total number of MPs in individual terms does not equal 200 due to turnovers and exclusion of some MPs.

In 1996, the proportion of female MPs increased to nearly 15 per cent and remained more or less stable for another ten years. A substantial change started in 2006 and fully blossomed in 2010, when the proportion rose above the level of 20 per cent. The reason for this was a decrease in the preferential vote share threshold (from 7 to 5 per cent), which allowed a candidate to move up on a candidate list more easily. The modification benefited female candidates more than men (Stegmaier et al., 2014). Since then, approximately a fifth of Czech MPs have been women. Despite the different electoral system to the upper parliamentary house, the descriptive representation of women in the Senate is only a few percentage points lower (Šprincová, Adamusová, 2014). ${ }^{6}$

The number of female MPs substantially differed across the parties. To assess the most important parties, the Christian Democrats (10.53 per cent) and the Civic Democrats (13.31 per cent) had the lowest share of women deputies during this time. Contrary to this, the Communists comprised 29.78 per cent of female representatives, which was the highest figure among the large parties. Surprisingly, the share of female Social Democrats was only 15.63 per cent, which was closer to the two conservative parties than the Communists. On the contrary, the female representation of TOP 09 (26.98 per cent) was relatively high, considering the party's conservative tendencies. Overall, although conservative parties tended to be represented by fewer women than leftist parties, similarly to Western Europe, there were a few exceptions.

The legislators' gender is an independent variable in the presented analysis. Besides this, I employ several dependent variables of the deputies' legislative behaviour. They portray the functions of the lower house - these are controlling a cabinet, articulation

${ }^{6}$ Here, it is essential to provide some additional facts in depicting the Czech political landscape. Currently, there are no statutory gender quotas, either for composing candidate lists or electing a certain proportion of women on any level of politics. Despite this, the number of female candidates has been increasing - in the 1990s, there were approximately 15 per cent of female politicians on candidate lists for legislative election; since 2002, the figure has not fallen below 25 per cent (Czech Statistical Office, 2019). Since the number of female candidates is continuously higher than the number of elected female MPs, one of the problems is that female politicians usually do not get attractive positions on candidate lists (Linek, 2009). The analyses show that women are more likely to be elected in larger constituencies, and less likely in the staunchly Catholic Moravian region (Rakušanová, 2004). Considering the major political parties, gender quotas for composing party offices are set up only in the statutes of the Greens for now (Stegmaier et al., 2014). Moreover, the party also has formal gender rules for the formation of candidate lists for elections to the Chamber of Deputies. In 2013, the female Christian Democrats alone composed half of the party members (Šprincová, Adamusová, 2014). Other major parties have approximately one-third of female members, with the exception of the Communists, with more than 40 per cent of women members. Overall, the data suggest that descriptive representation of women is unequal not only on the national level of politics but also on the regional and local levels, with approximately 20-25 per cent of female politicians (Rakušanová, 2004; Šprincová, Adamusová, 2014; Hájek, 2019). 
of people's voice, adoption of laws, and electoral role (Vodička, Cabada, 2011). Furthermore, the selection of the dependent variables follows the logic of contemporary research on legislative behaviour.

To be more specific, I inspect the voting attendance of MPs during plenary meetings. Next, I deal with their voting activity, which is operationalised as a percentage of active voting (either Yes or No) compared to abstentions. Besides this, I am interested in the number of bills that a deputy proposed annually either alone or in a group. ${ }^{7}$ Next, I track the annual number of both oral and written interpellations delivered by a deputy. Last but not least, I scrutinise the effect of gender on the number of speeches that an MP addressed at plenary meetings per year.

Figure 1. Differences between the activity of male and female MPs in individual terms

a) Proposed bills per year

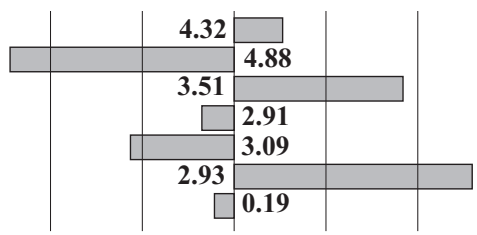

c) Interpellations per year

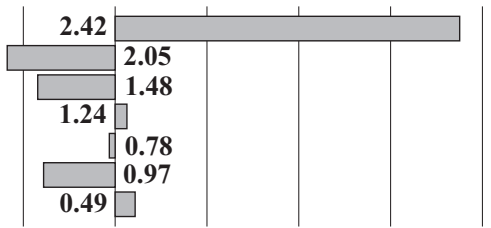

e) Post-election memberships in

(sub)committees and commissions

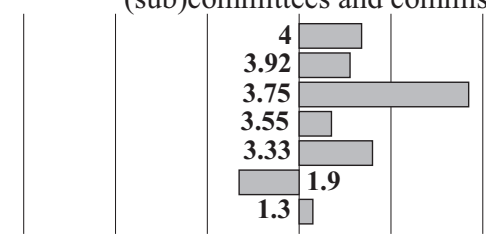

g) Post-election presidium posts in

(sub)committees and commissions

b) Voting attendance $(\%)$

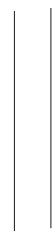

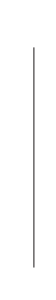

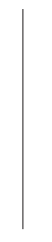

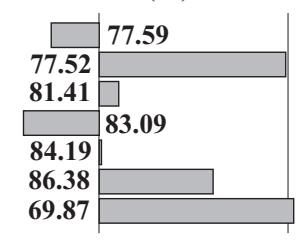

d) Voting activity (\%)

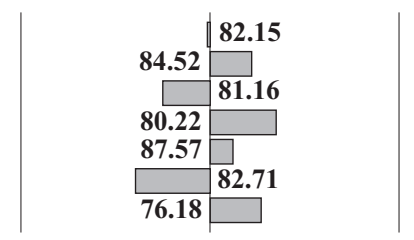

f) Speeches per year
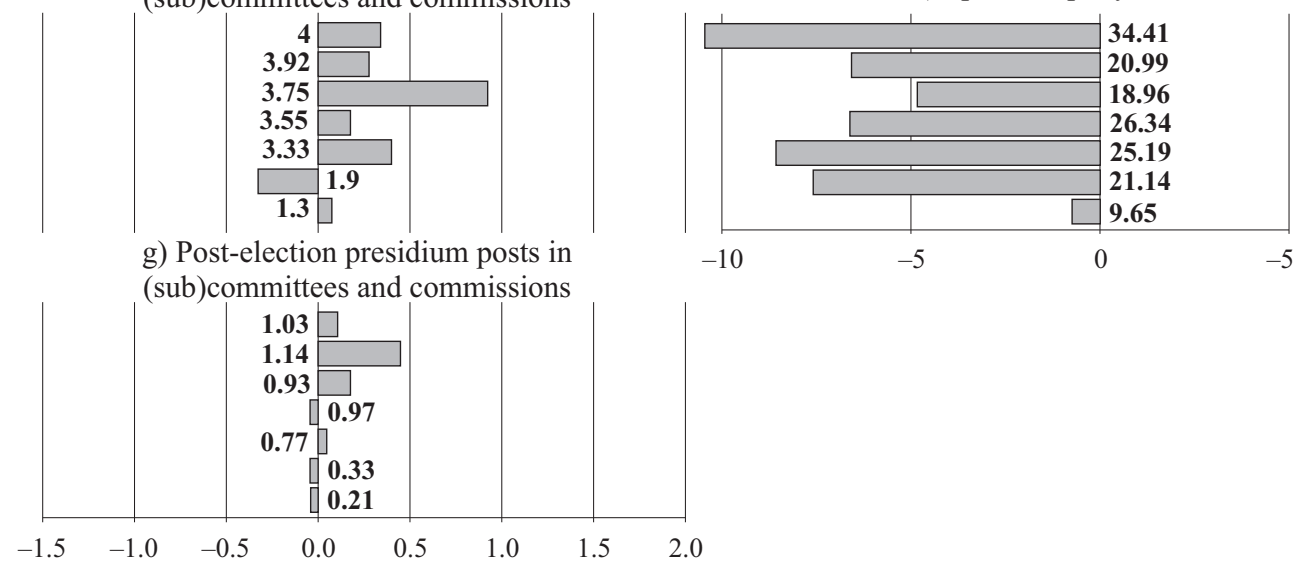

Note: The baseline numbers represent the average parliamentary activity of male MPs. The bars illustrate the difference compared to female activity. The bars stand for seven parliamentary terms since 1993-1998 (the bottom bars) until 2013-2017 (the upper bars).

${ }^{7}$ Czech MPs have the right to propose new laws either individually or in groups. Besides MPs, bills can be proposed by the cabinet, the Senate, or representative bodies of higher self-governing regions. 
Next, I track the effect of the MPs' gender on the total number of memberships in parliamentary committees, subcommittees, and commissions. Thus, I am interested in the number of positions held six months after legislative elections. Similarly, I inspect the quantity of MPs' presidium positions in the intra-parliamentary bodies at the very same time. Last but not least, I also quantify the effect of gender on the chances of becoming a member of particular committees.

To get a more detailed picture of the dependent variables, Figure 1 displays the average parliamentary performance of female MPs compared to their male colleagues in different terms. In the case of proposed bills, delivered interpellations, and voting activity, it is not possible to discover any pattern. The differences between males and females seem to be arbitrary. On the contrary, the measures of voting attendance and the number of post-election memberships and presidium posts in (sub)committees and commissions are rather dominated by female MPs.

The differences in the number of speeches given are unique compared to the rest of the dependent variables. In all seven parliamentary terms, women took the microphone, on average, less frequently than men. Furthermore, the contrast has been predominantly increasing during the last 25 years, with only a few exceptions. However, only multivariate modelling can discover whether these differences are also significant in the light of alternative explanations.

To build up multivariate models, I employ several control variables that have been proven to influence MPs' parliamentary performance. I identify degree holders (Hurka et al., 2018), the age of MPs (Mocan, Altindag, 2013), and their tenure (Best, Vogel, 2017). The analysis also considers the geographical distance of the legislators' constituencies from Prague, where the Chamber of Deputies resides (Weinberg et al., 1999). Since being a ruling party MP rather than an opposition deputy substantially influences MPs' legislative behaviour, I employ this variable as well. I also track whether the deputy served in the PPG presidium, since such officers have a priority right to address plenary meetings. The analyses also control the overall number of MPs' memberships in the chamber's bodies, as presence in such bodies requires significant additional activity. Last but not least, I also use dummy variables of party affiliations and parliamentary terms (Proksch, Slapin, 2012; Mocan, Altindag, 2013).

\section{Results}

I utilise several types of modelling on the grounds of distribution of the data to discover the true nature of gender's effect on the MPs' legislative behaviour. The legislators' voting attendance and voting activity are close to a normal distribution. Thus, Table 2 shows models of bivariate and multivariate ordinary least squares regression analyses.

The results show that gender does not significantly affect the representatives' voting attendance at plenary meetings. Although the bivariate model 1 shows the statistical significance of gender influence, the effect disappears as soon as the dummy variables of parliamentary terms are included. More detailed analysis suggests that gender affected MPs' parliamentary attendance mainly between 2002 and 2006, as the interaction effect between the term dummy and being a female MP was negative. However, the effect is not present in general. 
This finding may be surprising, since several other factors seem to be influential (e.g. age, tenure, geographical area, or being a ruling party MP). Overall, the multivariate model 2 of voting attendance is convincing since it explains almost 30 per cent of the dependent variable's variance. To explain this, in Czech politics, being exceptional in voting attendance does not provide substantial political gains or cost anything. Therefore, there is not enough motivation for female MPs to excel in any way.

Table 2

OLS regression analyses of voting attendance and activity

\begin{tabular}{|c|c|c|c|c|}
\hline & \multicolumn{4}{|c|}{ Dependent variable: } \\
\hline & \multicolumn{2}{|c|}{ Voting attendance } & \multicolumn{2}{|c|}{ Voting activity } \\
\hline & Model 1 & Model 2 & Model 3 & Model 4 \\
\hline \multirow[t]{2}{*}{ Female } & $1.652^{*}$ & 0.785 & 0.690 & $0.784^{*}$ \\
\hline & $(0.896)$ & $(0.782)$ & $(0.590)$ & $(0.423)$ \\
\hline \multirow[t]{2}{*}{ Age } & & $0.184^{* * *}$ & & $0.077^{* * *}$ \\
\hline & & $(0.032)$ & & $(0.017)$ \\
\hline \multirow[t]{2}{*}{ Tenure } & & $-1.921^{* * *}$ & & $-1.313^{* * *}$ \\
\hline & & $(0.331)$ & & $(0.179)$ \\
\hline \multirow[t]{2}{*}{ Degree holder } & & -1.034 & & $-0.774^{*}$ \\
\hline & & $(0.736)$ & & $(0.398)$ \\
\hline \multirow[t]{2}{*}{ Geographic area } & & $0.993^{* * *}$ & & $0.312^{* *}$ \\
\hline & & $(0.289)$ & & $(0.156)$ \\
\hline \multirow[t]{2}{*}{ PPG (vice-)chairman } & & $1.514^{*}$ & & 0.767 \\
\hline & & $(0.867)$ & & $(0.469)$ \\
\hline \multirow[t]{2}{*}{ Ruling party MP } & & $4.227^{* * *}$ & & $5.265^{* * *}$ \\
\hline & & $(0.736)$ & & $(0.398)$ \\
\hline Chamber's & & $-3.447^{* *}$ & & -0.271 \\
\hline (vice-)president & & $(1.734)$ & & $(0.939)$ \\
\hline (Sub)committee and & & $0.701^{* * *}$ & & $0.181^{* *}$ \\
\hline commission memberships & & $(0.146)$ & & $(0.079)$ \\
\hline Dummy variables of terms (6) & & $\vdots$ & & $\vdots$ \\
\hline Dummy variables of parties (16) & & $\vdots$ & & $\vdots$ \\
\hline \multirow[t]{2}{*}{ Constant } & $79.966^{* * *}$ & $63.432^{* * *}$ & $81.959^{* * *}$ & $76.318^{* * *}$ \\
\hline & $(0.370)$ & $(2.289)$ & $(0.244)$ & $(1.239)$ \\
\hline $\mathrm{N}$ & 1,385 & 1,385 & 1,385 & 1,385 \\
\hline $\mathrm{R}^{2}$ & 0.002 & 0.296 & 0.001 & 0.523 \\
\hline Adjusted $\mathrm{R}^{2}$ & 0.002 & 0.279 & 0.0003 & 0.512 \\
\hline F statistic & $\begin{array}{c}3.398^{*} \\
(\mathrm{df}=1 ; 1,383)\end{array}$ & $\begin{array}{c}18.313^{* * *} \\
(\mathrm{df}=31 ; 1,353)\end{array}$ & $\begin{array}{c}1.367 \\
(\mathrm{df}=1 ; 1,383)\end{array}$ & $\begin{array}{c}47.903^{* * *} \\
(\mathrm{df}=31 ; 1,353)\end{array}$ \\
\hline
\end{tabular}

Note: Control dummy variables of terms and parties are hidden to save space. $\mathrm{p}$-Values: $\mathrm{p}<0.01={ }^{* * *}$, $\mathrm{p}<0.05={ }^{* *}, \mathrm{p}<0.1{ }^{*}$.

Contrary to this, there is an arguable effect of gender on MPs' voting activity. On the one hand, the effect of gender is significant only on a level of 90 per cent confidence. Furthermore, the effect is not revealed in bivariate model 3. On the other hand, model 4 is very robust, since it explains more than half of the variation of the deputies' voting activity. Keeping everything else constant, male MPs voted actively in 78.90 per cent of the votes they attended between 2013 and 2017 ( \pm 1.3 percentage points with 95 per cent 
confidence intervals). ${ }^{8}$ Women, in turn, voted actively in 79.68 per cent of the cases $( \pm 1.5$ percentage points). If the simulation focuses on individual parliamentary terms, the effect of gender on MPs' voting activity remains approximately the same in all of them.

Even though the difference is less than a single percentage point, it is worth mentioning. The fact is that a higher rate of active voting increases the chances of attracting media that prefer to inform about explicit and confrontational policy positions. This can be beneficial to women seeking media attention to boost their political position. Besides this, the higher voting activity of women can be advantageous in the eyes of voters and party leaders. Such MPs look more politically determined, which could lead to better odds of being elected again.

The numbers of proposed bills, interpellations delivered, and speeches made are examples of count variables. Furthermore, distributions of the data have a larger variance than mean. Therefore, I employ negative binomial modelling to delineate the relationship.

Multivariate models 2 and 4 in Table 3 imply that there is no difference between male and female deputies considering bill proposals and interpellations. Given the theoretical background, the result is particularly surprising in the case of bill sponsorship. On the one hand, the bivariate model 1 implies a positive relationship between the MPs' gender and the number of proposed bills. On the other hand, the effect vanishes in the multivariate modelling as soon as it controls for being a ruling party MP and the number of memberships in intra-parliamentary bodies. Below, in text, I show that female MPs are overrepresented in these bodies, which explains the seeming effect of gender, which is rather caused by the number of (sub)committee and commission positions held.

Since the analysis does not identify the content of the bills, it is only possible to say that the activity is gender-neutral in general. However, it may also be the case that either female or male MPs cosponsor bill proposals rather than write them from scratch. Unfortunately, the research design of the analysis is not able to examine this surmise.

The models of interpellations delivered may be distorted by the fact that 51 per cent of the deputies did not deliver a single question. Thus, it is difficult to reveal any relationship. Nonetheless, as the percentage of the inactive deputies suggests, the activity does not seem to be crucial to the idle majority of MPs.

More importantly, there is a considerable effect of gender on the MPs' speechmaking. This is an essential difference as participating in plenary debates attracts both direct and indirect media and voter attention. Keeping everything else constant, during the last term of office, male representatives gave 25.61 speeches per year with 95 per cent confidence intervals between 21.00 and $30.87 .{ }^{\circ}$ Contrary to this, female legislators spoke only 20.03 times annually $(16.06 ; 24.66)$. The difference of more than five speeches a year confirms H1.

${ }^{8}$ The simulations of the multivariate models are conducted under the setting of opposition unexperienced degree holders of average age from the Prague and Central Bohemian Region without any experience with the chamber's and PPG presidium post, with the average number of memberships in committees, subcommittees, and commissions, and affiliated to the Social Democrats (a coalition party) during the VII Chamber of Deputies.

9 The simulations of the multivariate models are conducted similarly to how the previous note explains it. 
Negative binomial models of bills, interpellations, and speeches

\begin{tabular}{|c|c|c|c|c|c|c|}
\hline & \multicolumn{6}{|c|}{$\begin{array}{l}\text { Dependent variable: } \\
\end{array}$} \\
\hline & \multicolumn{2}{|c|}{ Proposed bills } & \multicolumn{2}{|c|}{$\begin{array}{c}\text { Delivered } \\
\text { interpellations }\end{array}$} & \multicolumn{2}{|c|}{ Addressed speeches } \\
\hline & Model 1 & Model 2 & Model 3 & Model 4 & Model 5 & Model 6 \\
\hline \multirow[t]{2}{*}{ Female } & $0.116^{*}$ & 0.048 & 0.184 & 0.033 & $0.143^{*}$ & $-0.246^{* * *}$ \\
\hline & $(0.062)$ & $(0.040)$ & $(0.136)$ & $(0.119)$ & $(0.087)$ & $(0.062)$ \\
\hline \multirow[t]{2}{*}{ Age } & & -0.001 & & -0.0002 & & $-0.006^{* *}$ \\
\hline & & $(0.002)$ & & $(0.005)$ & & $(0.003)$ \\
\hline \multirow[t]{2}{*}{ Tenure } & & 0.023 & & 0.014 & & $0.243^{* * *}$ \\
\hline & & $(0.016)$ & & $(0.048)$ & & $(0.026)$ \\
\hline \multirow[t]{2}{*}{ Degree holder } & & 0.040 & & 0.153 & & $0.271^{* * *}$ \\
\hline & & $(0.039)$ & & $(0.121)$ & & $(0.059)$ \\
\hline \multirow[t]{2}{*}{ Geographic area } & & $0.029^{*}$ & & $0.161^{* * *}$ & & -0.029 \\
\hline & & $(0.015)$ & & $(0.045)$ & & $(0.023)$ \\
\hline PPG & & $0.157^{* * *}$ & & -0.054 & & $0.513^{* * *}$ \\
\hline (vice-)chairman & & $(0.043)$ & & $(0.141)$ & & $(0.067)$ \\
\hline \multirow[t]{2}{*}{ Ruling party MP } & & $-1.026^{* * *}$ & & $-2.287^{* * *}$ & & $-0.489^{* * *}$ \\
\hline & & $(0.041)$ & & $(0.135)$ & & $(0.058)$ \\
\hline Chamber's & & 0.040 & & 0.439 & & $2.845^{* * *}$ \\
\hline (vice-)president & & $(0.091)$ & & $(0.286)$ & & $(0.132)$ \\
\hline (Sub)committee & & $0.025^{* * *}$ & & $0.138^{* * *}$ & & $0.047^{* * *}$ \\
\hline $\begin{array}{l}\text { and commission } \\
\text { memberships }\end{array}$ & & $(0.007)$ & & $(0.021)$ & & $(0.011)$ \\
\hline Dummy variables of terms (6) & & $\vdots$ & & $\vdots$ & & $\vdots$ \\
\hline Dummy variables of parties (16) & & $\vdots$ & & $\vdots$ & & $\vdots$ \\
\hline \multirow[t]{2}{*}{ Constant } & $1.118^{* * *}$ & $1.838^{* * *}$ & $0.279^{* * *}$ & $0.841^{* *}$ & $3.435^{* * *}$ & $2.839^{* * *}$ \\
\hline & $(0.026)$ & $(0.115)$ & $(0.057)$ & $(0.343)$ & $(0.036)$ & $(0.180)$ \\
\hline $\mathrm{N}$ & 1,385 & 1,385 & 1,385 & 1,385 & 1,385 & 1,385 \\
\hline Log likelihood & $-3,084$ & $-2,240$ & $-2,071$ & $-1,742$ & $-6,135$ & $-5,510$ \\
\hline Theta & $\begin{array}{l}2.243^{* * *} \\
(0.158)\end{array}$ & $\begin{array}{l}14.655 \\
(27.093)\end{array}$ & $\begin{array}{l}0.33^{* * *} \\
(0.020)\end{array}$ & $\begin{array}{l}0.748^{* * *} \\
(0.053)\end{array}$ & $\begin{array}{l}0.692^{* * *} \\
(0.024)\end{array}$ & $\begin{array}{l}1.544^{* * *} \\
(0.061)\end{array}$ \\
\hline AIC & 6,172 & 4,544 & 4,146 & 3,549 & 12,273 & 11,085 \\
\hline
\end{tabular}

Note: Control dummy variables of terms and parties are hidden to save space. $\mathrm{p}$-Values: $\mathrm{p}<0.01{ }^{* * *}$, $\mathrm{p}<0.05={ }^{* *}, \mathrm{p}<0.1={ }^{*}$.

Contrary to this, Bäck and Debus (2016) discovered no effect in the Czech Republic. However, they scrutinised only a single (and a politically unique) term and employed a different model. Since the presented multivariate model utilises complex data on the MPs' legislative behaviour between 1993 and 2017, it can be considered more robust.

Figure 2 displays separate simulations of individual parliamentary terms. It suggests that the effect of female deputies speaking less frequently was statistically significant in all seven parliamentary terms. Furthermore, the difference has become larger during the last 25 years as it increased from approximately two speeches per year in 1993-1998 to almost six speeches in 2013-2017. Interestingly, the difference remained relatively low between 2006 and 2013. It is not a coincidence that during the two terms, the share of female MPs in the chamber rose noticeably. Thus, the effect is linked to a general perception of women's presence in the chamber. 
Figure 2. Marginal effects of gender on speechmaking in individual terms

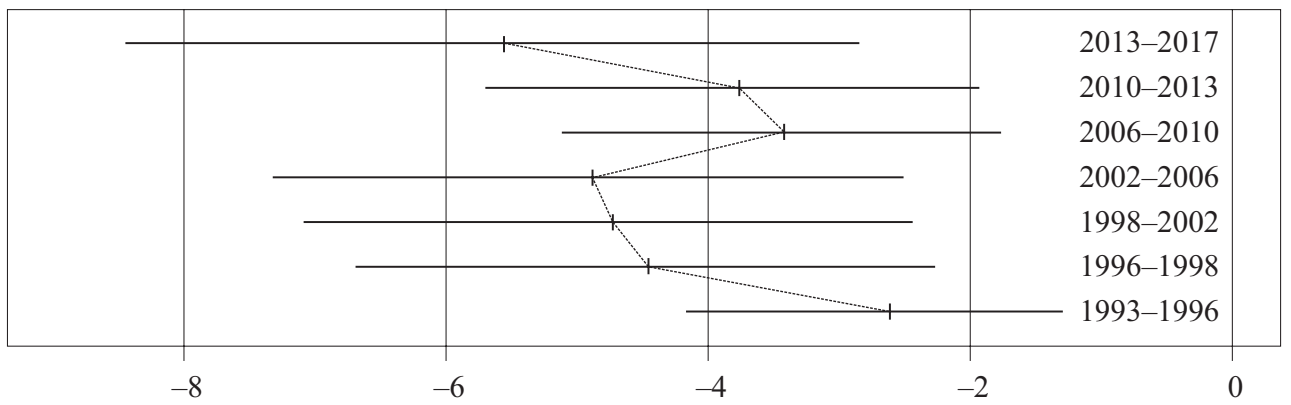

Annual number of speeches addressed by female MPs compared to males

Note: The expected values and associated 95 per cent confidence intervals are depicted using the simulation of the Zelig package in R (Venables, Ripley, 2008).

Although the research design of the presented analysis does not deliver any detailed explanation of this effect, the most straightforward explanation is that female MPs speak less on 'hard policy' issues (Bäck et al., 2014; Bäck, Debus, 2016). Such an explanation is also supported by the findings in Figure 4 below.

Although the numbers of post-election positions in committees, subcommittees, and commissions are count variables as well, it is necessary to employ different modelling. The reason for this is that the data have a similar mean and variance. Thus, I reveal the relationships using Poisson modelling. Besides this, since the dependent variables are limited by the exact point in time of six months after legislative elections, the following analyses deal only with 1,302 MPs who held a deputy mandate at that point in time.

Table 4 shows the results that are in agreement with hypothesis H2. To be more specific, female MPs get more post-election membership positions in the intra-parliamentary bodies. The same effect also applies to presidium posts. The latter difference especially is a precious advantage for female MPs, since (vice-)chairmen can significantly influence the political agenda. These undisputed relationships are suggested not only by the bivariate models but also by the multivariate analyses.

Table 4

Poisson models of post-election positions in intra-parliamentary bodies

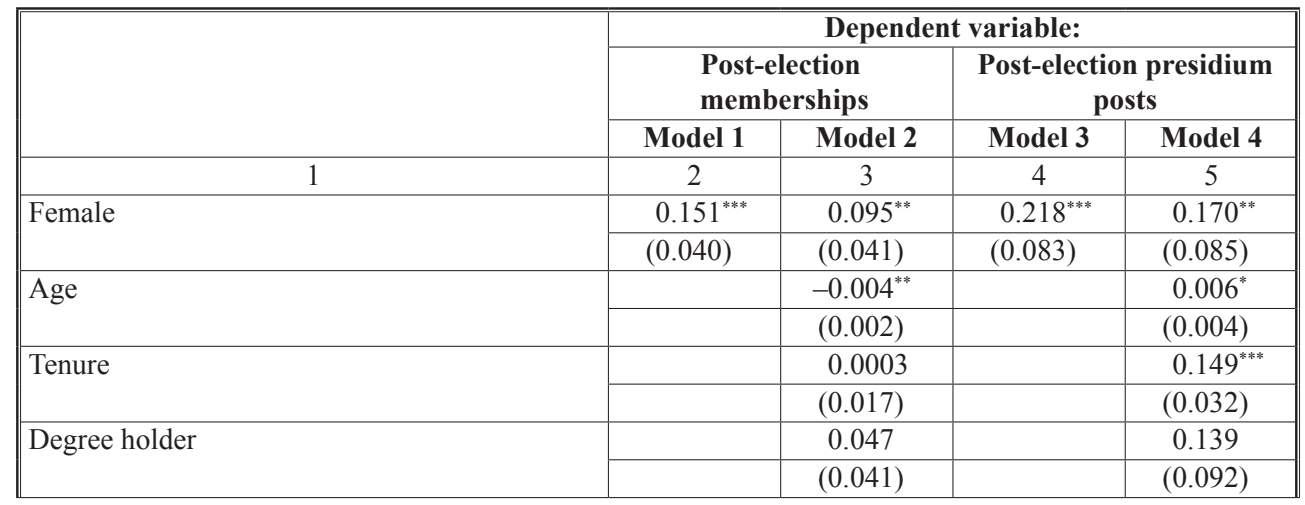




\begin{tabular}{|l|c|c|c|c||}
\hline \multicolumn{1}{|c|}{1} & 2 & 3 & 4 & 5 \\
\hline \multirow{2}{*}{ Geographic area } & & 0.005 & & -0.017 \\
\cline { 2 - 5 } & & $(0.016)$ & & $(0.033)$ \\
\cline { 2 - 5 } & & 0.049 & & -0.029 \\
\hline \multirow{2}{*}{ Ruling party MP } & & $(0.045)$ & & $(0.095)$ \\
\cline { 2 - 5 } & & $0.086^{* *}$ & & 0.019 \\
\hline Chamber's & & $(0.039)$ & & $(0.081)$ \\
\hline (vice-)president & & $-0.410^{* * * *}$ & & $0.502^{* * *}$ \\
\hline Post-election & & $(0.108)$ & & $(0.153)$ \\
\hline (sub)committee and commission memberships & & & & $0.116^{* * *}$ \\
\hline Dummy variables of terms (6) & & $\vdots$ & & $(0.020)$ \\
\hline Dummy variables of parties (16) & & $\vdots$ & & $\vdots$ \\
\hline Constant & $1.117^{* * * *}$ & $1.456^{* * *}$ & $-0.405^{* * *}$ & $-1.350^{* * *}$ \\
\cline { 2 - 5 } & $(0.017)$ & $(0.115)$ & $(0.037)$ & $(0.268)$ \\
\hline $\mathrm{N}$ & 1,302 & 1,302 & 1,302 & 1,302 \\
\hline Log likelihood & $-2,511$ & $-2,235$ & $-1,352$ & $-1,208$ \\
\hline AIC & 5,026 & 4,531 & 2,709 & 2,480 \\
\hline
\end{tabular}

Note: Control dummy variables of terms and parties are hidden to save space. $\mathrm{p}$-Values: $\mathrm{p}<0.01=^{* * *}$, $\mathrm{p}<0.05={ }^{* *}, \mathrm{p}<0.1{ }^{*}$.

To inspect the magnitude of the effects, Figure 3 depicts a simulation of the relationships in individual terms. ${ }^{10}$ While male deputies held four mandates in the intraparliamentary bodies half a year after the elections in 2013, female MPs got almost 0.4 mandates more. This finding suggests that women occupy more positions in commit-

Figure 3. Effect of gender on post-election positions in intra-parliamentary bodies

a)

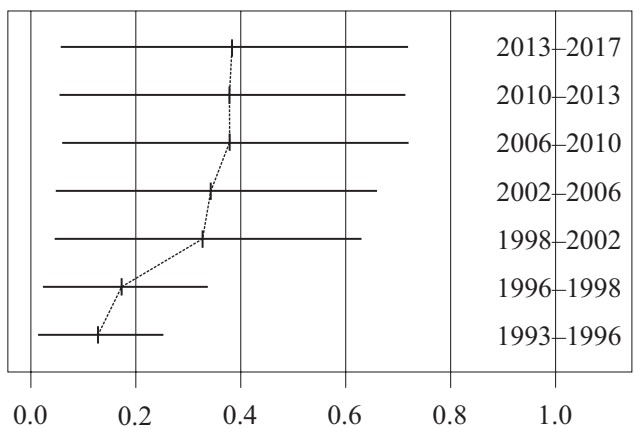

Post-election memberships of female MPs compared to males b)

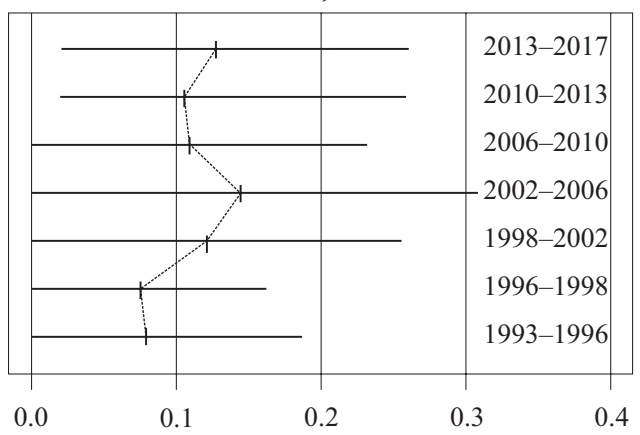

Post-election praesidium posts of female MPs compared to males

Note: The expected values and associated 95 per cent confidence intervals are depicted using the simulation of the Zelig package in R (Venables, Ripley, 2008).

${ }^{10}$ The simulations of the multivariate models are conducted under the setting of opposition unexperienced degree holders of average age from the Prague and Central Bohemian Region without any experience with the chamber's and PPG presidium post, with the average number of post-election memberships in committees, subcommittees, and commissions, and affiliated to the Social Democrats (a coalition party). 
tees, subcommittees, and commissions compared to their male colleagues. Most importantly, female overrepresentation became more substantial during the seven terms. The trend shows that the difference tripled between the elections in 1993 and 2013.

The simulations of the post-election presidium posts held also suggest a moderate increase in female MPs' overrepresentation during the last 25 years. Paradoxically, the rise slowed between 2006 and 2013, when the share of women in the chamber increased. This suggests that the overrepresentation of women in the bodies' presidium is permanent, but it is lessened particularly in the terms when female candidates visibly succeed in the legislative elections.

The most straightforward explanation of the difference is that male deputies get more positions in cabinet and on the chamber's presidium. Therefore, either because of the Rules of Procedure of the Chamber of Deputies or by convention, female MPs get more positions in committees, subcommittees, and commissions. Nevertheless, the most prestigious committees still predominantly consist of male legislators (Rakušanová Guasti, 2009).

To demonstrate this, I scrutinise the chances of MPs of becoming members of particular committees. Since the dependent variables are binary options of either being or not being a member of a committee half a year after the elections, I employ logit modelling.

Figure 4 summarises the results of 13 separate multivariate models that include all the previously used control variables. ${ }^{11}$ Specific $p$-values of the gender effect are displayed next to the respective committees. The results show that there are only three committees with no statistically significant difference between the chances of male and female deputies to become their members. These are (1) the steering committee, (2) mandate and immunity committee, and (3) committee on foreign affairs. Thanks to the relatively high p-value, it is possible to consider the committee on environment as being gender-neutral as well.

Figure 4. Effect of gender on post-election chances of committee assignments

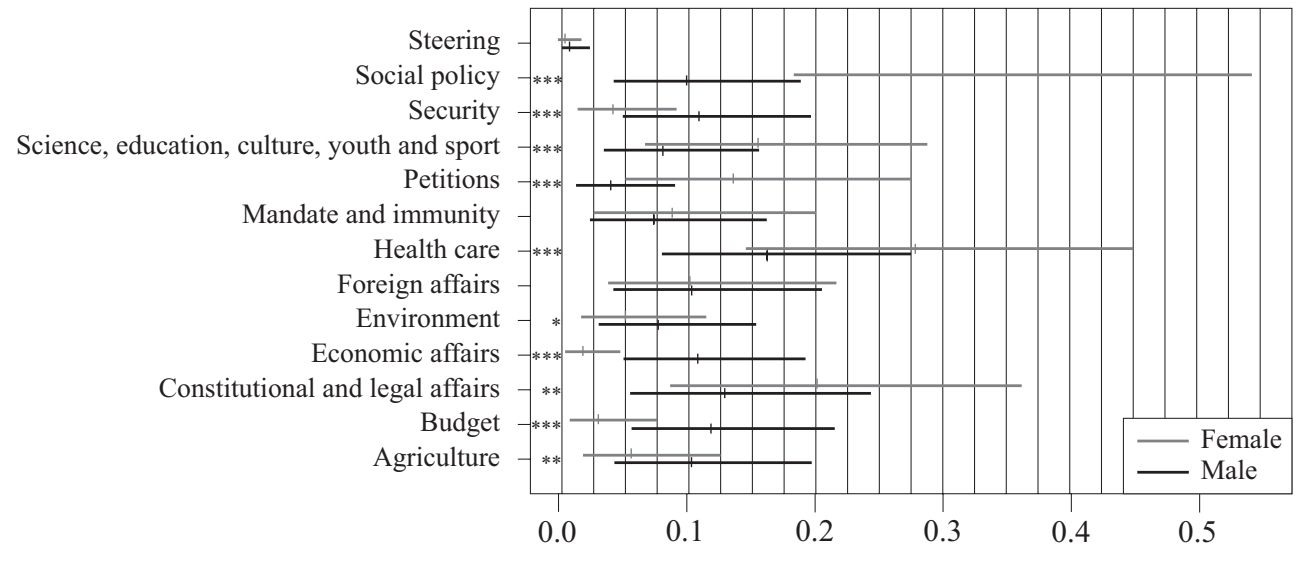

Predicted probabilities of being a committee member $(\mathrm{P})$

Note: $\mathrm{p}$-Values: $\mathrm{p}<0.01={ }^{* * *}, \mathrm{p}<0.05={ }^{* *}, \mathrm{p}<0.1={ }^{*}$. The expected values and associated 95 per cent confidence intervals are depicted using the simulation of the Zelig package in R (Venables, Ripley, 2008).

${ }_{11}$ The simulations of the multivariate models are conducted similarly to how the previous endnote explains it for the VII Chamber of Deputies. 
On the one hand, the models imply that female MPs have significantly higher chances of becoming members of five committees compared to men - these are the committees on (1) social policy, (2) science, education, culture, youth and sport, (3) petitions, (4) health care, and (5) constitutional and legal affairs. The difference is largest in the case of the social policy committee. To be more specific, keeping everything else constant, female legislators have a 34.78 per cent chance of becoming a member of the committee, while the chance of male MPs is only 9.95 per cent.

On the other hand, male deputies are more likely than female MPs to become members of four committees - these are the committees on (1) security, (2) economic affairs, (3) budget, and (4) agriculture. For instance, male MPs have an 11.80 per cent chance of becoming members of the budget committee. However, the very same probability in the case of female deputies is only 3.13 per cent. Interestingly, these findings are in perfect (!) agreement with hypotheses $\mathrm{H} 3 \mathrm{a}$ and $\mathrm{H} 3 \mathrm{~b}$. Thus, it is possible to infer that the difference between 'male and female committees' in the Czech Republic (a post-communist country) is similar to Sweden and Norway (Western Europe) (see Towns, 2003).

Finally, I have run several robustness analyses to assess the quality of the results. First, I have tested whether the effect of gender can interact with other independent variables. For instance, one may expect that gender is more influential for younger deputies, when they have to focus on childcare and their future political prospects simultaneously. However, no such interaction effect with either age, tenure, holding a degree, or geographical location was statistically significant.

All the results are also robust against excluding observations with large residuals. This robustness analysis mostly jeopardizes the effect of gender on the number of memberships held and presidium posts in intra-parliamentary bodies. The effects become gradually less statistically significant together with the exclusion of outliers.

To summarise, the results are robust against standard threats that usually distort the models. This is not surprising, since the dataset is rich in the number of observations and the variance of the data.

Conclusions

The article shows that gender does influence the parliamentary activity of MPs in the Czech Republic. Still, although the effect is noticeable, the differences are not radical, and they apply to only some parliamentary activity. Most importantly, gender tends to affect the legislative behaviour of MPs in a post-communist country similarly to that in Western Europe. This applies to the fewer speeches made by female MPs, the overrepresentation of women in intra-parliamentary bodies, and gender-biased committees. Based on these findings, the communist legacy of different modern social and political history does not seem to play a significant role here.

Generally, it is not possible to say that female deputies in the Czech Republic are more or less active than their male colleagues. There is no evidence that female legislators deliver different numbers of bills and interpellations, or attend more or less roll call votes than male representatives. It is true that there are more demanding selection criteria for female MPs in the Czech Republic, since they are politically underestimated by the public, and oppressed within male-driven parties (Galligan, Clavero, 2008; CVVM, 
2016). Nonetheless, this does not translate into more active female MPs in the parliament in general, similarly to US congresswomen (Anzia, Berry, 2011).

Most of the effects of gender on the legislative behaviour of Czech MPs follow trends from Western Europe. To be more specific, Czech women deputies speak less than their male colleagues, which is similar to female representatives' behaviour in Finland, Norway, and Sweden (Bäck, Debus, 2016). Furthermore, Czech women get relatively more positions in committees, subcommittees, and commissions compared to their male counterparts. The effect is in accord with the findings from the British House of Commons (O'Brien, 2012). Last but not least, the results of the differences between gender-neutral, male-biased, and female-biased committees are in perfect agreement with conclusions from Sweden and Norway (Towns, 2003).

These findings are important, as they show that similar differences exist on both sides of the former Iron Curtain, despite the different experiences of social and political systems. Nonetheless, I have only shown that the similarity applies to the directions of the gender effect. Thus, it is a task for further studies to compare also the strength of the effect.

Interestingly, it is exciting to inspect the dynamics of gender influence on the legislative behaviour of Czech MPs. Concerning females speaking less and getting relatively more positions in the chamber's bodies, the differences between the genders have been predominantly increasing during the last 25 years. Nonetheless, the distinctions were rising mainly when the share of female MPs remained low compared to the previous term. On the contrary, when the share of women deputies rose significantly in 2006 and 2010, the effect of gender on the number of speeches given and positions received became smaller.

This finding shows a link between the descriptive representation of women in the chamber and their parliamentary performance compared to male deputies. As long as the low share of women remains stable, the differences between the two genders become larger. However, as soon as the share of female MPs increases notably, the differences tend to be lesser. To summarise, a course towards an equal descriptive representation leads to the more equal parliamentary activity of female and male MPs.

Since this paper is a pioneering study, it deals with descriptive representation. Therefore, it seems natural to follow it with scrutiny of similarities between the substantial representation of women in Western Europe and the post-communist area. Moreover, an interesting question for qualitative study would be whether the fundamental reasons why female MPs behave differently from male deputies are the same in both regions. We should also scrutinise whether both male and female MPs are content with the differences, or whether they want to change the status quo.

Generally, it would be beneficial to make more use of post-communist legislatures and societies in the study of female representation (see Gwiazda, 2019a). For instance, Rosenbluth (2006) argues that women's representation in politics is closely associated with the development of the welfare state. Since the generosity of welfare states in postcommunist countries is approximately in between the Scandinavian countries and the rest of Western Europe, the post-communist area can serve as an exciting and so far underrated research case. 
Descriptive statistics of variables (1993-2017)

Supplementary table

\begin{tabular}{|l|r|r|r|c|c|}
\hline \multicolumn{1}{|c|}{ Variable } & N & Mean & $\begin{array}{c}\text { Standard } \\
\text { deviation }\end{array}$ & $\begin{array}{c}\text { Mini- } \\
\text { mum }\end{array}$ & $\begin{array}{c}\text { Maxi- } \\
\text { mum }\end{array}$ \\
\hline Female & 1,385 & 0.17 & 0.38 & \multicolumn{1}{c|}{0} & 1 \\
\hline Voting attendance (\%) & 1,385 & 80.25 & 12.55 & 1.73 & 99.62 \\
\hline Voting activity (\%) & 1,385 & 82.08 & 8.26 & 49.81 & 100 \\
\hline Proposed bills per year & 1,385 & 3.12 & 2.72 & 0 & 16.19 \\
\hline Interpellations per year & 1,385 & 1.37 & 3.35 & 0 & 38.22 \\
\hline Speeches per year & 1,385 & 31.84 & 76.59 & 0 & 857 \\
\hline $\begin{array}{l}\text { (Sub)committees and commissions post-election mem- } \\
\text { berships }\end{array}$ & 1,302 & 3.14 & 1.77 & 0 & 12 \\
\hline $\begin{array}{l}\text { (Sub)committees and commissions post-election pre- } \\
\text { sidium posts }\end{array}$ & 1,302 & 0.69 & 0.71 & 0 & 4 \\
\hline Age & 1,385 & 46.83 & 9.88 & 21.4 & 77.27 \\
\hline Tenure & 1,385 & 1.68 & 1.01 & 1 & 7 \\
\hline Degree holder & 1,385 & 0.79 & 0.40 & 0 & 1 \\
\hline Geographic area & 1,385 & 2.31 & 1.02 & 1 & 4 \\
\hline PPG (vice-)president & 1,385 & 0.14 & 0.35 & 0 & 1 \\
\hline Cabinet MP & 1,385 & 0.44 & 0.50 & 0 & 1 \\
\hline Chamber's (vice-)president & 1,385 & 0.03 & 0.17 & 0 & 1 \\
\hline Sub)committees and commissions memberships & 1,385 & 4.12 & 2.47 & 0 & 15 \\
\hline
\end{tabular}

Note: Horizontal lines distinguish between independent, dependent, and control variables.

\section{Bibliography}

Anzia S. F., Berry C. R. (2011), The Jackie (and Jill) Robinson effect: Why do congresswomen outperform congressmen?, "American Journal of Political Science", vol. 55, no. 3.

Bäck H., Debus M. (2016), Political parties, parliaments and legislative speechmaking, Palgrave Macmillan, Houndmills-Basingstoke-Hampshire-New York.

Bäck H., Debus M., Müller J. (2014), Who takes the parliamentary floor? The role of gender in speechmaking in the Swedish Riksdag, "Political Research Quarterly", vol. 67, no. 3.

Best H., Vogel L. (2017), The emergence and transformation of representative roles, in: Parliamentary roles in modern legislatures, eds. M. Blomgren, O. Rozenberg, Routledge, New York.

Brown A., Barnett Donaghy T., Mackay F., Meehan E. (2002), Women and constitutional change in Scotland and Northern Ireland, "Parliamentary Affairs", vol. 55, no. 1.

Childs S. (2004), A feminised style of politics? Women MPs in the House of Commons, "British Journal of Politics \& International Relations", vol. 6, no. 1.

Chiva C. (2018), Gender, institutions and political representation: Reproducing male dominance in Europe's new democracies, Palgrave Macmillan, Basingstoke.

CVVM (2016), Názory veřejnosti na roli muže a ženy v rodině - únor 2016, Centrum pro výzkum veřejného mínění, Sociologický ústav AV ČR.

Czech Statistical Office (2019), Results of elections and referendums, http://volby.cz/index_en.htm.

Debus M., Hansen M. E. (2014), Representation of women in the parliament of the Weimar Republic: Evidence from roll call votes, "Politics \& Gender", vol. 10, no. 3.

Diaz M. M. (2005), Representing women? Female legislators in West European parliaments, ECPR Press, Colchester.

Dovi S. (2002), Preferable descriptive representatives: Will just any woman, black, or latino do?, "American Political Science Review", vol. 96, no. 4. 
Dovi S. (2007), Theorizing women's representation in the United States, "Politics \& Gender", vol. 3, no. 3 .

Eisenstein Z. (1993), Eastern European male democracies: A problem of unequal equality, in: Gender politics and post-communism: Reflections from Eastern Europe and the former Soviet Union, eds. N. Funk, M. Mueller, vol. 303-318, Routledge, London.

Galligan Y., Clavero S. (2008), Prospects for women's legislative representation in postsocialist Europe: The views of female politicians, "Gender \& Society", vol. 22, no. 2.

Galligan Y., Clavero S., Calloni M. (2007), Gender politics and democracy in post-socialist Europe, Barbara Budrich Publishers, Opladen-Farmington Hills.

Geys B., Mause K. (2014), Are female legislators different? Exploring sex differences in German MPs' outside interests, "Parliamentary Affairs", vol. 67, no. 4.

Grebelsky-Lichtman T., Bdolach L. (2017), Talk like a man, walk like a woman: an advanced political communication framework for female politicians, "The Journal of Legislative Studies", vol. 23 , no. 3.

Gwiazda A. (2017), Women in parliament: assessing the effectiveness of gender quotas in Poland, "The Journal of Legislative Studies", vol. 23, no. 3.

Gwiazda A. (2019a), Introduction to the special issue on politics and gender in Eastern Europe, "Politics \& Gender", vol. 15, no. 2.

Gwiazda A. (2019b), The substantive representation of women in Poland, "Politics \& Gender", vol. 15, no. 2.

Hájek L. (2019), Whose skin is in the game? Party candidates in the Czech Republic, "East European Politics", vol. 35, no. 3.

Heath R. M., Schwindt-Bayer L. A., Taylor-Robinson M. M. (2005), Women on the sidelines: Women's representation on committees in Latin American legislatures, "American Journal of Political Science", vol. 49, no. 2.

Heidar K., Pedersen K. (2006), Party feminism: Gender gaps within Nordic political parties, "Scandinavian Political Studies", vol. 29, no. 3.

Hogan R. E. (2008), Sex and the statehouse: The effects of gender on legislative roll-call voting, "Social Science Quarterly", vol. 89, no. 4.

Htun M., Lacalle M., Micozzi J. P. (2013), Does women's presence change legislative behavior? Evidence from Argentina, 1983-2007, "Journal of Politics in Latin America", vol. 5, no. 1.

Hurka S., Daniel W. T., Obholzer L. (2018), Determinants of moonlighting in the European Parliament, "The Journal of Legislative Studies", vol. 24, no. 1.

Ilonszski G. (2006), Women in politics: The European Union and Hungary, in: Changing roles: Report on the situation of women and men in Hungary 2005, eds. I. Nagy, M. Pongrácz, I. n. G. r. Tóth, TÁRKI Social Research Institute, Budapest, pp. 56-68.

Ilonszski G., Vajda A. (2019), Women's substantive representation in decline: The case of democratic failure in Hungary, "Politics \& Gender", vol. 15, no. 2.

Inglehart R. (1977), The silent revolution: changing values and political styles among western publics, Princeton University Press, Princeton.

Inter-Parliamentary Union (2019), “Women in national parliaments, http://archive.ipu.org/wmn-e/classif.htm.

Jankowski M., Marcinkiewicz K., Gwiazda A. (2019), The effect of electing women on future female candidate selection patterns: Findings from a regression discontinuity design, "Politics \& Gender", vol. 15 , no. 2 .

Jeydel A., Taylor A. J. (2003), Are women legislators less effective? Evidence from the U.S. House in the 103rd-105th Congress, "Political Research Quarterly", vol. 56, no. 1.

Koch M. T., Fulton S. A. (2011), In the defense of women: Gender, office holding, and national security policy in established democracies, "The Journal of Politics", vol. 73, no. 1. 
Linek L. (2009), Socio-demografická struktura poslancủ a její vliv na politické postoje, in: Český parlament ve druhé dekádě demokratického vývoje, eds. Z. Mansfeldová, L. Linek, Sociologický ústav AV ČR, Praha, pp. 95-111.

Lloren A. (2015), Women's substantive representation: Defending feminist interests or women's electoral preferences?, "The Journal of Legislative Studies", vol. 21, no. 2.

Loewenberg G., Patterson S. C. (1979), Comparing legislatures, Little Brown, Boston.

Madsen J. K. (2019), Voter reasoning bias when evaluating statements from female and male political candidates, "Politics \& Gender", vol. 15, no. 2.

Mansfeldová Z. (2011), Central European parliaments over two decades - diminishing stability? Parliaments in Czech Republic, Hungary, Poland, and Slovenia, "The Journal of Legislative Studies", vol. 17, no. 2.

Mansfeldová Z., Linek L. (2009), Český parlamentarismus: přehled, in: Český parlament ve druhé dekádě demokratického vývoje, eds. Z. Mansfeldová, L. Linek, Sociologický ústav AV ČR, Praha, pp. 23-38.

Matland R. E. (2005), Enhancing women's political participation: Legislative recruitment and electoral systems, in: Women in parliament: Beyond numbers, eds. J. Ballington, A. Karam, International Institute for Democracy and Electoral Assistance, Stockholm, pp. 93-110.

Matland R. E., Montgomery K. A. (2003), Recruiting women to national legislatures: A general framework with applications to post-communist democracies, in: Women's access to political power in post-communist Europe, eds. R. E. Matland, K. A. Montgomery, vol. 19-42, OUP Oxford, Oxford.

Mocan N., Altindag D. T. (2013), Salaries and work effort: An analysis of the European Union parlamentarians, "The Economic Journal", vol. 123, no. 573.

Moser R. G. (2001), The effects of electoral systems on women's representation in post-communist states, "Electoral Studies", vol. 20, no. 3.

Norris P., Lovenduski J. (1995), Political recruitment: Gender, race and class in the British Parliament, Cambridge University Press, Cambridge.

O'Brien D. Z. (2012), Gender and select committee elections in the British House of Commons, "Politics and Gender", vol. 8, no. 2.

Phillips A. (1995), The politics of presence, Clarendon Press, Oxford.

Pitkin H. F. (1967), The concept of representation, University of California Press, Berkeley.

Proksch S.-O., Slapin J. (2012), Institutional foundations of legislative speech, “American Journal of Political Science", vol. 56, no. 3.

Rakušanová Guasti P. (2009), Role poslance a jeji percepce, in: Český parlament ve druhé dekádě demokratického vývoje, eds. Z. Mansfeldová, L. Linek, Sociologický ústav AV ČR, Praha, pp. $112-20$.

Rakušanová P. (2004), Zpráva o řešení projektu výzkumu a vývoje pro potřeby státu, Sociologický ústav Akademie věd České republiky, Praha.

Rosenbluth F., Salmond R., Thies M. F. (2006), Welfare works: Explaining female legislative representation, "Politics \& Gender", vol. 2, no. 2.

Rueschemeyer M., Wolchik S. L. (eds.) (2009), Women in power in post-communist parliaments, Indiana University Press, Bloomington.

Saxonberg S. (2000), Women in East European parliaments, "Journal of Democracy”, vol. 11, no. 2.

Šprincová V., Adamusová M. (2014), Politická angažovanost žen v České republice. Přehledová studie (1993-2013), Fórum 50\%, Praha.

Stegmaier M., Marcinkiewicz K., Jankowski M. (2016), The effects of electoral rules on parliamentary behavior: A comparative analysis of Poland and the Czech Republic, "East European Politics and Societies and Cultures", vol. 30, no. 4. 
Stegmaier M., Tosun J., Vlachová K. (2014), Women's parliamentary representation in the Czech Republic: Does preference voting matter?, "East European Politics and Societies and Cultures", vol. 28 , no. 1.

Thomas S. (1994), How women legislate, Oxford University Press, Oxford, UK.

Towns A. (2003), Understanding the effects of larger ratios of women in national legislatures: Proportions and gender differentiation in Sweden and Norway, "Women \& Politics", vol. 25, no. 1/2.

Tremblay M. (1998), Do female MPs substantively represent women? A study of legislative behaviour in Canada's 35th parliament, "Canadian Journal of Political Science", vol. 31, no. 3.

Venables W. N., Ripley B. D. (2008), negbin: Negative binomial regression for event count dependent variables in Christine Choirat, James Honaker, Kosuke Imai, Gary King, and Olivia Lau, 'Zelig: Everyone's statistical software,' http://zeligproject.org/, vol. no.

Vodička K., Cabada L. (2011), Politický systém České republiky: historie a současnost, Portál, Praha.

Wängnerud L. (2000), Testing the politics of presence: Women's representation in the Swedish Riksdag, "Scandinavian Political Studies", vol. 23, no. 1.

Wängnerud L. (2009), Women in parliaments: Descriptive and substantive representation, "Annual Review of Political Science", vol. 12, no. -.

Weinberg A., Cooper C. L., Weinberg A. (1999), Workload, stress and family life in British members of parliament and the psychological impact of reforms to their working hours, "Stress Medicine", vol. 15 , no. 2.

Wilson W. C., Carlos R. F. (2014), Do women representatives regender legislative bureaucracy? Assessing the effect of representative sex on women's presence among US Congressional staff, "The Journal of Legislative Studies", vol. 20, no. 2.

Wolbrecht C., Campbell D. E. (2007), Leading by example: Female members of parliament as political role models, "American Journal of Political Science", vol. 51, no. 4.

\section{West Side Story w postkomunistycznym parlamencie: Wpływ płci na zachowania legislacyjne posłów do parlamentu}

\section{Streszczenie}

Istnieje wiele dowodów na to, że płeć wpływa na ustawodawcze zachowania posłów. Niemniej jednak, jako że większość ustaleń pochodzi z Europy Zachodniej, można zadać pytanie, czy taka zależność zachodzi również w postkomunistycznych parlamentach. Ponieważ oba regiony miały różną historię związaną z płcią, odpowiedź negatywna sugeruje się sama. Natomiast pierwsze kompleksowe badania nad tym zagadnieniem przeprowadzone w państwie postkomunistycznym pokazują coś przeciwnego. Jako przypadek badawczy wykorzystana została działalność parlamentarna przedstawicieli w Czechach w latach 1993-2017. Wyniki analizy pokazują, że choć posłanki mówią mniej, otrzymują więcej stanowisk w organach wewnątrzparlamentarnych niż posłowie płci męskiej. Ponadto większość komisji jest daleka od neutralności płciowej, ponieważ ustawodawcy płci męskiej i żeńskiej mają znacząco różne szanse na to, by zostać ich członkami. Ogólnie rzecz biorąc, wyniki sugerują, że płeć wpływa na zachowanie parlamentarzystów w państwach postkomunistycznych, zaskakująco podobnie jak w Europie Zachodniej.

Słowa kluczowe: płeć, parlament, zachowania ustawodawcze, Republika Czeska, Izba Deputowanych 
